\title{
The impact of women's co-operative in a rural area in achieving Sustainable Development Goals (SDGs)
}

\section{Dampak koperasi perempuan di pedesaan dalam mencapai Tujuan Pembangunan Berkelanjutan (SDGs)}

\author{
Rustinsyah Rustinsyah ${ }^{1 *}$, Pudjio Santoso ${ }^{1}, \&$ Nurul Ratna Sari ${ }^{2}$ \\ ${ }^{1}$ Department of Anthropology, Faculty of Social and Political Sciences, Universitas Airlangga \\ ${ }^{2}$ School of Arts and Humanities, Edith Cowan University \\ Address: ${ }^{1}$ Jalan Dharmawangsa Dalam, Airlangga, Surabaya, East Java, Indonesia 60286 \\ 22 Bradford Street, Mount Lawley, Western Australia, Australia 6050 \\ E-mail: rustinsyah@fisip.unair.ac.id*,pudjio.santoso@fisip.unair.ac.id, \& sari.unair@gmail.com
}

Article History: Received 7 August 2020; Accepted 13 January 2020; Published Online 19 January 2021

\begin{abstract}
One of the strategies to address the issue of poverty in rural areas is by empowering women. East Java provincial government, Indonesia, has allocated grants for women's co-operatives in rural areas since 2015, in the same year of the Sustainable Development Goals (SDGs) launch. This study describes the pattern of credit use in the women's co-operative and its impact on low-income family livelihoods. The research was conducted at two women's co-operatives in Plumpang District, Tuban Regency, Indonesia, from October 2017 to May 2018 using the qualitative approach. The data were collected through observation, in-depth interviews, focus group discussion, and survey about the co-operative members' credit use. This study found that the co-operative members used the loans for daily needs, tuition fees, agricultural activities, and non-farming economic activities. The co-operative has increased children's participation in low-income family informal education and strengthens social capital among poor people in rural areas; however, the co-operative still cannot cut the chain between low-income families and moneylenders the village. Consequently, further development of cooperatives in terms of quality and quantity is necessary for achieving the SDGs.
\end{abstract}

Keywords: credit usage; low-income family; education improvement; women's co-operative

\begin{abstract}
Abstrak
Salah satu strategi untuk mengatasi masalah kemiskinan di pedesaan adalah dengan pemberdayaan perempuan. Pemerintah Provinsi Jawa Timur, Indonesia, telah mengalokasikan dana hibah untuk koperasi perempuan di pedesaan sejak 2015, ditahun yang sama dengan peluncuran Tujuan Pembangunan Berkelanjutan (SDGs). Penelitian ini bertujuan untuk mendeskripsikan pola penggunaan kredit pada koperasi perempuan dan pengaruhnya terhadap kehidupan keluarga miskin. Penelitian dilakukan di dua koperasi wanita di Kecamatan Plumpang, Kabupaten Tuban, Indonesia dengan menggunakan pendekatan kualitatif. Pengumpulan data dilakukan melalui observasi, wawancara mendalam, diskusi kelompok terarah, dan survei penggunaan kredit anggota koperasi. Studi ini menemukan bahwa anggota koperasi menggunakan pinjaman untuk kebutuhan sehari-hari, biaya sekolah, kegiatan pertanian, dan kegiatan ekonomi non-pertanian. Koperasi telah meningkatkan partisipasi anak-anak dari keluarga miskin dalam pendidikan formal dan memperkuat modal sosial bagi masyarakat miskin di pedesaan; namun, koperasi masih belum bisa memutuskan rantai antara beberapa keluarga miskin dan rentenir di desa. Oleh karena itu, pengembangan koperasi lebih lanjut dalam hal kualitas dan kuantitas diperlukan untuk mencapai SDGs.
\end{abstract}

Kata kunci: penggunaan kredit; keluarga miskin; pemberdayaan pendidikan; koperasi wanita

\section{Introduction}

In September 2015, the United Nations launched the Sustainable Development Goals (hereafter called SDGs) as a global agenda to continue the previous global agenda's efforts and achievements, namely Millennium Development Goals (MDGs). The SDGs have 18 goals to be achieved, including life with no poverty, zero hunger, good health and well-being, quality education, and gender equality. One of the government's strategies to support the SDGs is to empower co-operative and 
microfinance institutions in rural areas. One of the support from the East Java provincial government is by giving grants to women's co-operatives. A women's co-operative is a co-operative in which the members and the administrators are women. Women are expected to contribute by increasing the family income and overcoming the economic problem for their daily living necessities (Trivendi et al. 2011); therefore, they can improve the families' welfare (Seng 2018). Women's co-operative is a rural microfinance institution as a savings and loan business, especially for women from lowincome families. This program contributes to increasing economic and social empowerment (The International Labour Organization 2015, United Nation Woman 2018); however, this co-operative is a business institution that is managed and provides mutual benefits. For example, co-operative lend money with a short process without interest or with low interest. Business co-operatives are a private company owned by a particular community by combining consumers and owners, with buyers and sellers in a democratic management structure. It is necessary to develop savings and loan activities provided by co-operatives following government regulations to expand and support productive business opportunities so that people can gain benefits and achieve prosperity.

The existence of co-operatives considers being beneficial for women. The study of Mujanah et al. (2019) found that women's co-operatives help their members meet social needs, improve welfare, and increase women's businesses. It is because the role of co-operatives is to empower women to be productive. Activities in women's co-operatives include group meetings and microcredit activities. Previous studies have shown that women's co-operatives can develop women's economies in rural areas and support family welfare (Sungkawati \& Suarniati 2015, Widiyanti et al. 2018, Sungkawati et al. 2018). By joining and becoming members of women's co-operatives, women entrepreneurs get many benefits, including social and business networks. Haryono et al. (2020) explained that women get business strategies from this social community to increase their competence and effectiveness. The existence of women's co-operatives is also a place for women to build broad relationships. Previous studies have also found that women's co-operatives can prevent women from poverty due to economic powerlessness (Anisykurlillah \& Latifah 2014, Rustinsyah 2017).

The government issued the Regulation of the Minister of Co-operative and Small and Medium Enterprises, the Republic of Indonesia, Number 02/Per./M.KUKM/II/2017 on the amendment of the previous regulation on saving and loan services. The regulation is in line with Article 33 of the 1945 Constitution, which states that a co-operative is an enterprise appropriate for the Indonesian economy. Indonesian co-operative serve as a business entity like firms and corporations and as the agent of development to alleviate poverty and improve local communities prosperity. According to the Law of Co-operatives Number 17 of the year 2012, the co-operative types are outlined in article 82, stating that every co-operative shall state the type in their statutes. Furthermore, in article 83, based on the similarity of business activities and/or the members' economic interests, there are four co-operatives: consumer co-operatives, producer co-operative, service, and savings and loan co-operatives.

Co-operatives are a form of community economic development. A study by Agusalim et al. (2019) states that co-operatives can pull people out of poverty because co-operatives have a social welfare pillar. When a co-operative is appropriately built and runs smoothly, it will affect the macro development process. Co-operatives will also have a micro effect, namely increasing the income of members. Previous studies have found that co-operatives can improve business strategies, so that co-operative members can compete and develop in terms of production processes, capital, and marketing networks (Haryono et al. 2021, Riswan et al. 2017, Utomo \& Pangeran 2020). The Indonesian government has an essential role in the existence of co-operatives to support people's economy. The study of Umiroh \& Hardiyani (2013) shows that the government encourages businesses to become members of cooperatives to feel empowerment and co-operatives' results. The co-operative management model is also based on the principle of cooperation, in which the implementation adjusts the community business. Previous studies have shown that co-operatives have social capital, namely norms, beliefs, and cooperation capabilities, strengthening the empowerment relationship to increase household welfare (Saskara \& Marhaeni 2018, Yuliarmi et al. 2020). 
Savings and Loans Co-operatives as financial institutions, which are included as intermediary institutions, are operational in line with co-operatives' principle principles. According to the Regulation of the Minister of Co-operatives and Micro, Small and Medium Enterprises (MSME) Number 15/Per/M.KUKM/2015, Article 19:

Savings and loan business activities include collecting deposits from members; provide loans to members, prospective members of co-operatives, other co-operatives, and/or members; and managing funding sources and lending. As referred to in paragraph (1), prospective members of the co-operative should become the co-operative members within a period of no later than three months. Savings and loan business activities with other co-operatives are carried out through partnerships as outlined in written agreements.

The women's co-operative is the flagship program of the East Java provincial government. The Department of Co-operatives and Small and Medium Enterprises (SMEs) of East Java Province initially aimed to reduce moneylenders in the village and empower villages through micro-enterprises. For this reason, the East Java provincial government gives grants to the women's co-operative. In 2015, the number of women's co-operatives in East Java that had received grants amounted reaching 6.238 co-operatives, and those that received one revolt were 2.268 co-operatives. The total grant channeled by the East Java provincial government amounted to 368.6 billion IDR with a total capital turnover of two times. Co-operative programs in East Java are considered successful; therefore, the governor of East Java received an award from the Indonesian government as the best co-operative's driver and the growth of entrepreneurship in 2017. The award was presented directly by the Minister of Co-operative of the Republic of Indonesia. The existence of women's co-operative as one of the microfinance institutions in rural areas benefits low-income families in rural areas to get cash to do their business and fulfill their needs. Therefore, this paper focuses on how co-operatives' impacts, particularly the women's co-operatives, improve low-income families' livelihood.

A co-operative is categorized as a microfinance institution that has basic principles. The basic principles of co-operatives in Indonesia are: voluntary membership, democratic management, Remaining Business results or Sisa Hasil Usaha (SHU) carried out somewhat based on the business services size, limited capital remuneration, independence, co-operative education, cooperation between co-operatives. A microfinance institution is an institution providing financial services for poor and low-income communities (Hamada 2010). Generally, such an institution provides loans of a small amount of money with low-interest and without any guarantee. According to Robinson \& Fidler (2001), microfinance refers to small-scale financial services, particularly loans and savings. Loans provided for farmers, fishers, small business people who produce, recycled products, and repaired goods. In addition, Schreiner (2000) argued that microfinance is designed to improve impoverished communities' welfare through saving and loan services as a formal credit scheme. Microfinance services in the informal financial sector are essential for the poor. Microfinance institutions are known as institutions that provide financial services such as loans, insurance, and saving for poor communities. Unlike conventional financial services, loan services in microfinance institutions do not require any guarantee (Littlefield et al. 2003). Trust is an essential factor for service companies.

The co-operative is also access to finance for its members. The study of Fianto et al. (2018) found that co-operatives, in general, are institutions that can create financial inclusion for the poor, improve community welfare, and reduce poverty. It can be achieved if there are effective regulation and supervision for the survival of the co-operative. Previous studies have shown that microcredit in cooperatives is the right method for empowering rural communities and as a tool to help marginalized communities (Santoso \& Ahmad 2016, Effendi 2013, Hadi et al. 2017). Generally, microfinance institutions offer low financial services to participate in economic activities, particularly concerning micro-business development. It expects to improve its domestic economy, manage its business autonomously, and make independent business decisions. Microfinance institutions expect to cope with unexpected problems, although there is no certainty to the potential to improve households' welfare (Armendariz \& Morduch 2010). 
The microcredit for women generally used as a strategy for empowering women. Ganle et al. (2015) found that women could be empowered by giving them access to loans. The microfinance program's target is poor women in developing countries to alleviate poverty and improve women empowerment (Haile et al. 2012). The rural women's co-operative, which received a grant from East Java Province, is one of the legal microfinance institutions. The existence of this co-operative will have an impact on its members.

Co-operatives' existence as one of the microfinance institutions may have positive and negative impacts on its members. Bateman (2010) argued that the effect of micro institutions that could improve the welfare of low-income communities was still debatable because some cases indicate that these institutions had both positive and negative impacts. Imai \& Azam (2012) stated that microcredit had a positive impact because it empirically could alleviate poverty. An empirical study in Bangladesh indicated that microcredit increased household income and expenditure, reduced income inequality, and empowered the community for welfare improvements (Imai \& Azam 2012). A study conducted by Akotey \& Adjasi (2016), in Ghana concluded that that microfinance could improve households' welfare. In Indonesia, according to Deloach \& Lamanna (2011), microcredit provides benefits to debtors. In Thailand, $19 \%$ of loans in a rural area is informal loans. Such loans only increase the asset of low households and the consumption of relatively wealthy people (Kislat 2015). On the contrary to the study conducted by Montgomery \& Weiss (2011) showed that the measurement done by Bank Khushhali as a microfinance institution in Pakistan that sets a higher interest compared to formal banking had a positive effect because the loans were used for education and health, particularly for children's medical needs. It could reduce mortality and be in line with the SDGs program.

On the other hand, microcredit may also have a negative impact. In Bolivia, microcredit might increase child labor (Maldonado \& Gonzólez-Vega 2008), whereas, in India, microcredit could not be used to empower women (Garikipati 2008). In the Philippines, microcredit increased household income and expenditure, but low households suffered a setback (Kondo et al. 2008). Although microcredit empowered women in Ghana, some debtors could not manage their loans; some of them even could not repay their loans (Ganle et al. 2015). Likewise, the study conducted by Banerjee \& Jackson (2016) concluded that microfinance institutions in three villages in Bangladesh increased debt among the poor, exacerbated economic, social, and environmental vulnerability, and caused social capital damage among the poor. Women's co-operatives in this study are one of the microfinance institutions that provide credit services for women. It refers to the provision of financial services to low-income customers, including entrepreneurs. Financial services generally include savings and loans.

\section{Research Method}

This study involved two women's co-operatives, Karya Pertiwi in Kepoh Agung Village and Barokah in Magersari Village, Tuban Regency. Both women's co-operatives are considered successful, and each of the co-operatives received a US\$3.846 grant from the East Java provincial government for two terms. Although receiving the same grants, the two co-operatives developed differently.

Karya Pertiwi women's co-operative in Kepoh Agung Village, Plumpang District, Tuban Regency was established in 2010, holding business license Number 041/BH/XVI.28/414.055/2010. The initial capital of the co-operative was the grant from the East Java provincial government of US\$1.923. In 2013 , the co-operative received an additional US\$1.923 since it was considered successful by the Department of Co-operative Tuban. In addition to the grant, its venture capital is from principal savings of US\$9.61 per member, the mandatory monthly saving of US $\$ 0.38$ per member, and monthly voluntary savings of US $\$ 0.15$ per member. The requirements to be a co-operative member include a copy of an identity card or Kartu Tanda Penduduk (KTP), principal saving, mandatory saving, and voluntary saving. In 2016-2017, the members of Karya Pertiwi women's co-operative reached 95 individuals.

Barokah women's co-operative in Kedungrojo Village, Plumpang District, Tuban Regency with the legal entity Number 289/BH/XVI.28/414.055/2010. The co-operatives' establishment was initiated by the family welfare movement of Kedungrojo Village, supported by the East Java provincial 
government through its grant for women's co-operatives. In early 2010, the co-operative received a grant of US\$1.923. In the early establishment of this co-operative, the membership only consisted of 18 Family Welfare Development or Pembinaan Kesejahteraan Keluarga (PKK) members. Most of them were Kedungrojo Village boards' wife. A year after its establishment, the co-operative was evaluated and considered successful. In 2013, the co-operative received another grant of US\$1.923. The total amount of grants from the East Java provincial government is US\$3.846. The co-operative capital consists of grants of US\$3.846, principal savings, mandatory savings, and voluntary savings from its members, as well as part of the co-operative's revenue, which is allocated to the co-operative reserve fund. The division of funds allocation is based on the Constitution and Bylaws. In 2016, according to the boards of Barokah women's co-operative, the co-operative members consisted of 43 women from Kedungrojo Village.

Table 1.

Growth of venture capital, revenue and co-operative members of 2017

\begin{tabular}{lcc}
\hline \multicolumn{1}{c}{ Description } & Karya Pertiwi & Barokah \\
\hline Venture capital & US $\$ 6.607$ & US $\$ 5.223$ \\
Revenue & US $\$ 1.459$ & US $\$ 750$ \\
Members & 95 & 43 \\
\hline
\end{tabular}

Source: The financial report of Karya Pertiwi and Barokah women's co-operatives 2017 (processed by the authors)

Notes:

Venture capital of Karya Pertiwi women's co-operative:

1. Grant from the provincial government US\$3.846

2. Principal, mandatory, and voluntary savings US\$2.761

Venture capital of Barokah women's co-operative:

1. Grant from the provincial government US\$3.846

2. Principal, mandatory, and voluntary savings US\$1.377

Table 1 shows that the venture capital of Karya Pertiwi is greater than Barokah. Since the beginning of the establishment of Barokah, the venture capital derived from the grant was used by one of the management members, causing no development and no new members registering. Later, the money was returned, and the co-operative began to operate normally to provide villagers opportunities to be members of microcredit activities. Such conditions created a negative image of the co-operative, leading to slow venture capital growth. It affected the number of members of the co-operative, which is less than that of Karya Pertiwi. The number of co-operative members affects co-operative venture capital as members should pay principal, mandatory and voluntary savings. The revenues used to cover the operational costs of the co-operative. In addition, $25 \%$ of the costs are distributed to the members as net income - the details of the use of revenues present in Table 2.

Table 2.

Karya Pertiwi and Barokah women's co-operatives' Revenue in 2017

\begin{tabular}{lcc}
\hline \multicolumn{1}{c}{ Description } & Karya Pertiwi (US\$) & Barokah (US\$) \\
\hline Operational Costs & 924 & 481 \\
Net Income & 535 & 268 \\
Total revenues & 1.459 & 750 \\
\hline
\end{tabular}

Source: Accountability report of Karya Pertiwi and Barokah women's co-operatives

(processed by the authors)

The revenue Karya Pertiwi women's co-operative is deducted by operational costs of US\$924 consisting of a) transportation costs for the boards to attend invitations from the Department of Co-operative, Tuban, for training activities, b) costs of coordinating with coordinators at the subdistrict level, and c) uniform for the boards. On the other hand, the revenue earned by Barokah in 2016 amounted to US\$750, deducted by operational costs of US\$481. The small amount of revenue 
was since two members had not repaid their loans of US\$268. The venture capital of Barokah is less than that of Karya Pertiwi. Operation costs of Barokah consist of transportation costs for the boards to attend pieces of training and coordination meetings with the coordinator at the sub-district level, uniforms, and other costs related to the boards' needs. The activities of co-operative boards include organizational development, education, training, and administrative development. The members of the co-operative receive income from the savings-loan activities. The amount of net income for each member is following members' participation in the savings and loans. For example, a housewife and a Karya Pertiwi ran a business selling daily necessities at home in 2016. She received a net income of US $\$ 34$. The net income was derived from loan services, principal savings, and mandatory savings.

Table 3.

Amount of net income received by members of Karya Pertiwi and Barokah women's co-operative

\begin{tabular}{ccccc}
\hline \multirow{2}{*}{$\begin{array}{c}\text { The amount of net } \\
\text { income received (US\$) }\end{array}$} & \multicolumn{2}{c}{ Karya Pertiwi } & \multicolumn{2}{c}{ Barokah } \\
\cline { 2 - 5 } & Amount & $\%$ & Amount & $\%$ \\
\hline$<3.8$ & 26 & 27 & 30 & 69 \\
$3.8-<7.7$ & 60 & 63 & 13 & 31 \\
$7.7-<15.38$ & 9 & 10 & - & - \\
\hline Total & $\mathbf{9 5}$ & $\mathbf{1 0 0}$ & $\mathbf{4 3}$ & $\mathbf{1 0 0}$ \\
\hline
\end{tabular}

Source: Net income report of Karya Pertiwi and Barokah women's co-operatives 2017

(processed by the authors)

Table 4.

Samples of Karya Pertiwi and Barokah women's co-operatives

\begin{tabular}{ccc}
\hline \multicolumn{1}{c}{ Sample } & Focus discussion group & Interviewers \\
\hline $\begin{array}{l}\text { Karya Pertiwi } \\
\text { (Member: 95) }\end{array}$ & $\begin{array}{c}\text { Each female group with 13 } \\
\text { participants }\end{array}$ & 7 \\
$\begin{array}{l}\text { Barokah } \\
\text { (Member: 43) }\end{array}$ & $\begin{array}{c}\text { Each female group with 10 } \\
\text { participants }\end{array}$ & 4 \\
\hline Total & $\mathbf{2 3}$ & $\mathbf{1 1}$ \\
\hline
\end{tabular}

Source: Accountability report and research data of Karya Pertiwi and Barokah women's co-operatives (processed by the author)

According to Table 3, Karya Pertiwi's net income is $63 \%$, ranged from US\$3.8 to US\$7.7. On the other hand, Barokah's net income is $69 \%$, which less than US\$3.8. There were even two members who only received US\$1.5 a net income. They were a low-income housewife who worked as a farmworker, and they could only afford a principal saving of US\$3.8 and US\$1.9 a mandatory saving. In 2017 , they had loans of US\$19.2, so that they only received US\$1.5 the net income.

The study conducts from October 2017 until May 2018. The study is a qualitative study aimed at understanding the implementation of women's co-operatives and their impact on poor rural families. Several steps were taken to collect the data: 1) the data were collected through a survey to obtain data on co-operative members' and credit users' identities, 2) in conjunction with the survey, qualitative data were collected through direct observations and interviews (Table 4), and 3) at monthly meetings of co-operatives' members, the focus discussion group was conducted. After the focus discussion group, then done in-depth interviews with co-operative boards, members with the highest revenue, members with the lowest revenue, members utilizing loans for non-agricultural businesses, members utilizing loans for agricultural costs, members utilizing loans for tuition fees, and other needs conducted. In addition, the author also examined documents related to co-operatives.

The data analysis followed several steps. First, the data collected from the questionnaires on loan usage were summarized into frequency tables, supported with cases of qualitative data associated with the questionnaire. Second, the data, consisting of interview transcripts, focus discussion group results, logbook, annual report, and observation notes were analyzed using Attride-Stirling's (2001) 
qualitative data analysis framework with the following stages. In the first stage, all transcripts from interviews and observation records transcribe. After being transcribed, the author interpreted the data. The data were then categorized into themes to answer the research problem. In the second stage, the transcripts were then grouped deductively and inductively and coded or labeled. In the third stage, a code system implements to answer the research problem. Finally, the identified themes were organized into a thematic chart to reflect basic and global themes.

\section{Results and Discussion}

\section{Loans usage}

Members of Karya Pertiwi were 95 low-income rural women, and the members of Barokah were 43 people. The members used the co-operative loans for various purposes and were generally housewives who worked as farmers and farm laborers. Some of them ran non-agricultural businesses such as trading foods and daily necessities, and they used loans for various needs. Table 5 shows the variation of loan usage by the members of the women's co-operatives. First, most of Karya Pertiwi (41\%) and Barokah (46\%) used the loans for input agriculture. The need for agricultural capital at the beginning of the planting season is indispensable because poor farmers as a tenant and generally managing a farm of fewer than 0.5 hectares cannot afford agricultural needs (chemical fertilizers, labors). The farmers' money from selling their harvests has been used for buying consumer goods, leaving only a few sacks of grain (approximately 100 kilograms) for food supplies. When farmers have cash in their hands, they use the cash to buy consumer goods and renovate their houses. Poor farmers' families' situation will worsen again if they experience a failure on the previous crop. Therefore they will not have cash reserves.

Table 5.

Loan usage of Karya Pertiwi and Barokah women co-operatives

\begin{tabular}{|c|c|c|c|c|}
\hline \multirow{2}{*}{ Loan Usage } & \multicolumn{2}{|c|}{ Karya Pertiwi } & \multicolumn{2}{|c|}{ Barokah } \\
\hline & Amount & $\%$ & Amount & $\%$ \\
\hline Daily needs & 30 & 31 & 15 & 35 \\
\hline Tuition fees & 10 & 10 & 3 & 8 \\
\hline $\begin{array}{l}\text { Agriculture (chemical fertilizer, } \\
\text { agricultural medicines) }\end{array}$ & 38 & 41 & 20 & 46 \\
\hline $\begin{array}{l}\text { Non-agricultural productive } \\
\text { enterprises (trading foods, fruits) }\end{array}$ & 9 & 9 & 2 & 5 \\
\hline Others & 8 & 9 & 3 & 6 \\
\hline Total & 95 & 100 & 43 & 100 \\
\hline
\end{tabular}

Second, $31 \%$ of Karya Pertiwi members and $35 \%$ of Barokah members used loans for daily needs. The definition of daily needs for low-income families in rural areas is very diverse. It includes expenses of daily expenditures, allowance for kids, paying the debt in nearby stalls, and donations for neighbors. Low-income families in a village commonly have debts in nearby stalls. Stalls in the rural area usually sell goods with the credit system. Customers will not buy goods in their stalls if they do not apply such a system. Therefore, co-operatives' loans are not directly used to meet daily needs but to pay debts installs. According to AK (46), one of the co-operative boards, the farm cannot be cultivated during the famine season in February. As a farm laborer, she does not earn during famine season. To meet her daily needs, she forces to borrow some money from the co-operative of US $\$ 15.38$ to pay her loan installs and other needs.

Third, co-operative members used loans for education needs, such as purchasing school supplies and tuition fees; it is usually done during the beginning of the academic year. At the beginning of the academic year, they need money to buy school supplies (bags, shoes) and entry tuition fees. 
Fourth, the co-operatives used the loans for trading fruits, foods, and other daily needs. Fifth, the cooperatives' members used the loans for other needs such as paying dues, recitals, and treatment for family members in illness.

\section{Debt portfolio of low-income families}

The existence of women's co-operatives in the countryside opens a new opportunity to get loans. This activity can add to several members' debt portfolio; moreover, low-income families' income in rural areas always related to physical conditions. This condition is related to their work represent as physical labor (for example, as farm laborers in the village). Thus, when they are sick and cannot work, they will not gain any income. In the case of daily necessities, life goes on and requires money to meet those needs. If the husband and the wife are sick, they cannot work to get money. Village stalls and food vendors may provide loans for daily necessities, and they usually do not apply any interest rates; however, the amount lent is minimal.

There are several cases among low-income families in the village that use "debts to pay debts." There are individuals or institutions, such as moneylenders and daily private banks, that provide loans to the village communities. Individuals or institutions that provide loans or credits attract highinterest rates. For example, Bank Keliling Desa (a bank that goes around the village, an informal money lender institution) provides small-scale loans without collateral but with high-interest rates. For example, the bank provides a loan of US\$7.10. The creditors must pay an administration of US\$0.35. Then, the loan must be returned every day with the amount of US\$0.35 24 times. The money lent from moneylenders usually used to pay installments in co-operatives or for other daily needs. Therefore, in some rural families, the women's co-operatives still cannot break the chain between low-income families with money lenders who offer credits or loans with an easy process, without using any collateral.

\section{Positive impacts of the co-operatives}

\section{Driving economic activities in rural areas}

The existence of women co-operatives in both villages has stimulated agricultural and non-agricultural economic activities for low-income populations. As previously mentioned, the co-operatives' loans were used for agricultural capital, trading capital, and other needs. Farming absorbs male and female laborers. Male laborers commonly prepare to land, such as hoeing, fertilizing, carrying crops. The wage for male laborers in this village is approximately US\$5 for farming from 07.00 to 12.00 . Female farm laborers commonly plant paddy, remove grass, harvest and collect rice leftovers. Therefore, during the planting season to harvest season, male and female farm laborers work in the morning to evening. In the morning, they work as hired farm laborers, and in the evening, they usually work on their farms or rent a farm. The rental price of agricultural land per hectare is around 30 million per year. Sometimes, the rental price is cheaper if the land location is relatively high or on the Bengawan Solo River banks. The agricultural land high landscape is usually tricky for irrigation systems, while in riverbank areas, usually in the rainy season is prone to flooding. Poor farmers rent 1.000 square meters of land with a three million rental price per year.

The availability of capital for farming moves the agricultural sector. The agricultural sector's success raises non-farm economic activities such as paddy middlemen, agricultural material traders (such as chemical fertilizers and agricultural chemicals), food traders, and daily needs vendors. The existence of traders makes it easier for farmers to sell their crops, obtain loans, and spends their money to meet their daily needs.

\section{Encouraging participation in formal education among low-income families}

The existence of women's co-operatives can encourage participation in formal education among low-income families. It is indicated by some members who used loans for education expenses such as buying school supplies and paying tuition fees. State schools do not require tuition fees until 
senior high school level; however, entry tuition fee, allowance, school supplies (books, bags, shoes), transportation costs are required for those who attend senior high school. Children do not need to go outside the village to attend elementary school because they already have one. Therefore, children of farmworkers in the village can continue their study in senior high school. Some low-income family children continue their education in higher education or at university.

\section{Strengthening the social capital of the rural population}

The participation in rural development activities of women from low-income families will strengthen social capital in rural areas. The participation strengthens the social capital of the members of these women's co-operatives through a budget allocation from net income for social activities, monthly meetings of members for saving and loan activities, the participation of co-operative members in religious and social activities. These women co-operative allocate budget for their members' education and social activities, as stated in the Constitution and Bylaws of the Co-operatives. The budget for education aims to help children of co-operative members who are underprivileged, while the social fund is for members who need specific issues such as illness and passing away.

Table 6.

Allocation of net income for social and education activities

\begin{tabular}{lcc}
\hline Net Income for social activity & Karya Pertiwi (US\$) & Barokah (US\$) \\
\hline Education fund (5\%) & 48.7 & 13.4 \\
Social fund (5\%) & 48.7 & 13.4 \\
\hline Source: Financial statements of Karya Pertiwi and Barokah women's co-operatives of 2017 \\
\end{tabular}

Table 6 shows that the social fund allocation is $5 \%$ of the co-operatives' net income. The amount of social fund of Karya Pertiwi is US\$48.7, and the one of Barokah only US\$13.4. The social fund provides for members who are in illness, pass away, or in trouble. Despite its insignificant amount, the members are pleased because of the attention of co-operative management. Besides, members of the co-operatives also personally donate to members who are ill.

The majority of co-operatives' members are Muslim, and they carry out religious, social activities. The members should pay dues for such activities, which include Tahlilan (weekly contribution of US\$3.8), Managibahan (monthly contribution of US\$1.5), Istighosah (monthly contribution of US\$ 1.5 ), and Muslimat (voluntary contribution of US\$0.2). Membership fees are used for uniforms, consumption, and social activities, such as visiting members who are ill. Co-operative members hold monthly meetings for saving and loan activities. The members use the meetings to interact with other co-operative's members. They usually share information about family and economic activities at the meetings, remind others about paying loans installment and talk about other cheating husbands' issues. Therefore, being a co-operative and member of a religious community can provide a sense of security and establish a sense of intimacy among fellow villagers to foster social capital among women in rural areas.

\section{Conclusion}

The two women's co-operatives in the villages were both established in 2010 , and they grew differently in terms of capital, revenues, and members. Karya Pertiwi had better capital growth compared to Barokah. It is due to: a) the higher number of Karya Pertiwi members. The size of the members affects the capital derived from principal savings and mandatory savings; b) Barokah did not grow fast because initially, the capital was used by one of the board members, causing the co-operative not to operate correctly and affect the amount of venture capital and revenues earned by the co-operative. The women co-operative provide loans with lower loan interest rates than the private lenders in the village and with negotiable periods of installments. It has benefited women from low-income families in the two villages, despite issues regarding delays in installment payments that can impede 
the co-operatives' financial circulation. The benefits of co-operative loans can be seen from the loan usage, which includes a) meeting daily needs, b) farming capital, c) educational expenses, d) farming activities, and e) non-farming economic activities.

The impact of the existence of women co-operatives in the village is a) driving economic activities in rural areas, b) encouraging participation in formal education among low-income families, c) strengthening the social capital of the rural population. All of these can support the achievement of the SDGs. Nevertheless, some village community members are still in the chain with moneylenders in the village. Consequently, the villages' co-operatives still need to be developed further in terms of quality and quantity so that the SDGs can be achieved more comprehensively. The recommendation from this study is that the co-operatives' management should continue to build trust from its members in managing the co-operatives so that the co-operatives can run smoothly and increase the social capital among poor rural families to improve welfare, education and encourage them to participate in rural development actively.

\section{References}

Agusalim L, Karim M, \& Yaddarabullah (2019) Indonesia cooperative and members welfare: A panel data analysis. Economics Development Analysis Journal 8 (1):9-21. https://doi. org/10.15294/edaj.v8i1.26830.

Akotey JO \& Adjasi CK (2016) Does microcredit increase household welfare in the absence of microinsurance? World Development 77 (2016):380-394. https://doi.org/10.1016/j.world dev.2015.09.005.

Anisykurlillah I \& Latifah L (2014) A model of women cooperative empowerment in improving community welfare. International Journal of Business, Economics and Law 5 (1):139-144.

Armendariz B \& Morduch J (2010) The Economics of Microfinance. New York: MIT Press.

Attride-Stirling J (2001) Thematic networks: An analytic tool for qualitative research. Qualitative Research 1 (3):385-405. https://doi.org/10.1177/146879410100100307.

Banerjee SB \& Jackson L (2016) Microfinance and the business of poverty reduction: Critical perspectives from rural Bangladesh. Human Relations 70 (1):63-91. https://doi.org/10.1177/ 0018726716640865.

Bateman M (2010) Why Doesn't Microfinance Work? The Destructive Rise of Local Neoliberalism. New York: Zed Books.

DeLoach SB \& Lamanna E (2011) Measuring the impact of microfinance on child health outcomes in Indonesia. World Development 39 (10):1808-1819. https://doi.org/10.1016/j. worlddev.2011.04.009.

Effendi J (2013) The Role of Islamic Microfinance in Poverty Alleviation and Environmental Awareness in Pasuruan, East Java, Indonesia. Göttingen: Universitätsdrucke Göttingen.

Fianto BA, Gan C, Hu B, \& Roudaki J (2018) Equity financing and debt-based financing: Evidence from Islamic microfinance institutions in Indonesia. Pacific-Basin Finance Journal 52 (2018):163-172. https://doi.org/10.1016/j.pacfin.2017.09.010.

Ganle JK, Afriyie K, \& Segbefia AY (2015) Microcredit: Empowerment and disempowerment of rural women in Ghana. World Development 66 (2015):335-345. https://doi.org/10.1016/j. worlddev.2014.08.027.

Garikipati S (2008) The impact of lending to women on household vulnerability and women's empowerment: Evidence from India. World Development 36 (12):2620-2642. https://doi. org/10.1016/j.worlddev.2007.11.008.

Hadi S, Wasahua O, \& Masri ZA (2017) Metode analisis SWOT dalam pelaksanaan one village one product agribisnis hortikultura (Studi kasus di Koperasi Mitra Tani Parahyangan Cianjur). Journal of Applied Business and Economic 4 (2):159-172. https://doi.org/10.30998/jabe. $\mathrm{v} 4 \mathrm{i} 2.2143$. 
Haile HB, Bock B, \& Folmer H (2012) Microfinance and female empowerment: Do institution matter? Women's Studies International Forum 35 (4):256-265. https://doi.org/10.1016/j. wsif.2012.04.001.

Hamada M (2010) Financial services to the poor: An introduction to the special issue on microfinance. The Developing Economies 48 (1):1-14. https://doi.org/10.1111/j.1746-1049.2010.00097.x.

Haryono A, Mudjiarto, Triatmanto B, \& Wahyuni N (2020) Descriptive analysis of cooperative management competency enhancement for increasing members' welfare and business strategies. In: Proceedings of the International Conference on Community Development (ICCD 2020), 18 July, [online]. 35-39.

Haryono A, Mudjiarto, Wahyuni N, \& Triatmanto B (2021) Competency improvement of cooperative managers to improve members' welfare by implementing business strategies. Management Science Letters 11 (3):975-982.

Imai KS \& Azam MDS (2012) Does microfinance reduce poverty in Bangladesh? New evidence from household panel data. The Journal of Development Studies 48 (5):633-653. https://doi. org/10.1080/00220388.2012.661853.

Kislat C (2015) Why are informal loans still a big deal? Evidence from North-East Thailand. The Journal of Development Studies 51 (5):569-585. https://doi.org/10.1080/00220388.2014.983907.

Kondo T, Orbeta AJ, Dingcong C, \& Infantado C (2008) Impact of microfinance on rural households in the Philippines. In: Discussion Papers, Philippine Institute for Development Studies.

Littlefield E, Murduch J, \& Hashemi S (2003) Is Microfinance an Effective Strategy to Reach the Millennium Development goals? In: CGAP Focus Notes.

Maldonado JH \& Gonzólez-Vega C (2008) Impact of microfinance on schooling: Evidence from poor rural households in Bolivia. World Development 36 (11):2440-2455. https://doi.org/10.1016/ j.worlddev.2008.04.004.

Miles MB \& Huberman AM (1983) Qualitative data analysis: A Methods Sourcebook. London: Sage.

Montgomery H \& Weiss J (2011) Can commercially-oriented microfinance help meet the Millennium Development Goals? Evidence from Pakistan. World Development 39 (1):87-109. https:// doi.org/10.1016/j.worlddev.2010.09.001.

Mujanah S, Brahmasari IA, Ratih IAB, \& Candraningrat C (2019) The impact of collective ambition, organizational culture, and organizational commitment on organizational citizenship behavior and the women's cooperatives' performance in East Java Indonesia. International Journal of Civil Engineering and Technology 10 (8):30-44.

Riswan R, Suyono E, \& Mafudi M (2017) Revitalization model for village unit cooperative in Indonesia. European Research Studies Journal 20 (4A):102-123.

Robinson MS and Fidler PJ (2001) The Microfinance Revolution, Sustainable Finance for the Poor. New York: World Bank

Rustinsyah R (2017) The microfinance institution and alleviation of poverty in an East Java Village, Indonesia. In: $1^{\text {st }}$ International Conference Postgraduate School Universitas Airlangga: Implementation of Climate Change Agreements to Meet Sustainable Development Goals.

Santoso B \& Ahmad K (2016) Islamic microfinance branchless banking model in Indonesia. Intellectual Discourse 24 (2016):409-433.

Saskara IAN \& Marhaeni AAIN (2018) Women's cooperative development strategy to improve their welfare: Case study in Gianyar Regency, Bali Province, Indonesia. IOSR Journal of Humanities and Social Science 23 (2):1-9.

Schreiner M (2000) Informal finance and the design of microfinance. Development in Practice 11 (5):637-640.

Seng K (2018) Rethinking the effects of microcredit on household welfare in Cambodia. The Journal of Development Studies 54 (9):1496-1512. https://doi.org/10.1080/00220388.2017.1299139.

Sungkawati E, Prawoto B, \& Mere K (2018) The business development of women's cooperatives through good corporate governance and joint responsibility. European Journal of Research and Reflection in Management Sciences 6 (4):27-34. 
Sungkawati E \& Suarniati NW (2015) Gender-based cooperative educational program on woman cooperative in Blitar Regency. European Journal of Business and Management 7 (36):36-41.

The International Labour Organization (2015) Global survey shows rising women's participation in cooperatives. [12 July 2020]. https://www.ilo.org/global/about-the-ilo/newsroom/news/ WCMS_349679/lang--en/index.htm.

Trivendi JC, Priyan PK, \& Venay B (2011) The role of dairy cooperatives in women empowerment. The IUP Journal of Agricultural Economics (1):41-51.

Umiroh IR \& Hardiyani R (2013) Agro-ecotourism management through cooperative based coffee plantation commodity to increase welfare of coffee farmer. Journal of Economics, Business and Management 1 (4):347-349.

United Nation Woman (2018) Women's cooperatives boost agriculture and savings in rural Ethiopia. [12 July 2020]. https://www.unwomen.org/en/news/stories/2018/7/feature-ethiopia-coope ratives-boost-agriculture-and-savings.

Utomo FXH \& Pangeran P (2020) Social entrepreneurship business model of coconut sugar for increasing farmers' welfare: Case study in Indonesian Village cooperative. International Journal of Multicultural and Multireligious Understanding 7 (7):830-840. https://doi. org/10.18415/ijmmu.v7i7.1915.

Widiyanti E, Pudjihardjo P, \& Saputra PMA (2018) Tackling poverty through women empowerment: The role of social capital in Indonesian women's cooperative. Jurnal Ekonomi dan Studi Pembangunan 10 (1):44-55. https://doi.org/10.17977/um002v10i12018p044.

Yuliarmi NN, Dunggio M, Yasa NM, \& Wright LT (2020) Improving public welfare through strengthening social capital and cooperative empowerment. Cogent Business Management 7 (1). https://doi.org/10.1080/23311975.2020.1841075. 